\title{
Crossing the Border to Memory: In Search of Clive Michael Boutilier $(1933-2003)^{1}$
}

\section{Marc Stein}

Marc Stein is an Associate Professor of History at York University in Toronto. He is the author of City of Sisterly and Brotherly Loves: Lesbian and Gay Philadelphia, 1945-1972 and the editor-in-chief of the Encyclopedia of Lesbian, Gay, Bisexual, and Transgender History in America.

$\mathrm{F}$ or more than a decade, I have been searching for Clive Michael Boutilier, who was deported from the United States to Canada in 1968. Boutilier's forced migration took place approximately 18 months after the U.S. Supreme Court ruled against him in a decision upholding the constitutionality of a 1952 U.S. law that provided for the exclusion and deportation of aliens "afflicted with psychopathic personality," a phrase interpreted to apply to "homosexuals" (Boutilier). ${ }^{2}$ What began for me as a graduate school seminar paper written within the framework of U.S. gay history has become the foundation of a larger and queerer book project that

${ }^{1}$ For their assistance, encouragement, comments, and suggestions, I thank Henry Abelove, Margot Canaday, Christopher Castiglia, Elizabeth Emens, Joyce Murdoch, Jorge Olivares, Christopher Reed, Tim Retzloff, Sharon Rosenberg, Marian Smith, Siobhan Somerville, torquere's anonymous readers, my many research assistants, and the niece of Clive Michael Boutilier. My research on Boutilier and Boutilier has been supported by York University and the Social Sciences and Humanities Research Council of Canada.

${ }^{2}$ The Supreme Court announced its decision on 22 May 1967, but according to Immigration and Naturalization Service File A10 082545 Boutilier was deported on 10 November 1968. I thank Marian L. Smith, Historian, U.S. Citizenship and Immigration Services, for supplying me with this information. The delayed deportation may reflect the post-ruling developments discussed below. 
juxtaposes the Court's "conservative" ruling in Boutilier with its "liberal" rulings in abortion, contraception, interracial marriage, and obscenity cases during the 1960 s and 1970 s. The book will explore the development of a classed, gendered, and racialized heteronormative legal regime in the United States and will do so through analyses of legal doctrine, movement strategy, and public reception. Yet even as the nature of my work has changed, I have remained drawn to Boutilier's "story" and have felt compelled to remember him. In this essay, I reflect on why this has been the case, taking the risk of self-critically examining my memorializing motivations. After introductory comments on queer memory, I describe my search for Boutilier, revealing in the process some of what I learned about him. Then I take an inventory of my interests, concluding with thoughts on the performance of queer remembrance.

\section{Queer Memory}

First I want to distinguish between the project of memorializing queers and the project of queering remembrance. In the last decade, the term "queer" has been used in multiple ways (Duggan, "Making It"; Stein, "Preface"): sometimes as a synonym for "lesbian and gay," "lesbian, gay, bisexual, and transgendered (LGBT)," or a longer list of terms; sometimes as a word that has had historically specific meanings in particular cultural contexts; sometimes as a concept that refers to sexes, genders, and sexualities that are dissident, resistant, subversive, or transgressive; and sometimes as a way of highlighting desires, practices, and identities that do not line up in normative ways. "Queer" can also refer to the rejection of coherent, fixed, and stable categories of sex, gender, and sexuality and to modes of analysis and types of processes that challenge the dominant (as in queering the state, queering the classroom, etc.). Comparing a recent generation of queer students to previous generations of lesbian/gay students, Henry Abelove has written:

Typically, the queers criticize the trope of marginalization that organizes many...[lesbian/gay] historical narratives; they resist the representation, relatively usual in these narratives, of persons as distinct, separate, and individual beings with deep subjectivity, who are capable of original and decisive action; they wax indignant whenever they find that these narratives figure persons as achieving authenticity through 
sex; and they worry about the way most of these narratives are framed by the nation-state. To put their position differently, they are interested in destabilizing identity in virtually every sense in the past as well as in the present, and they want the performance of that destabilization to be always primary. $(54)^{3}$

On one level, then, memorializing queers can refer to the process of remembering anyone from the past who can be identified as queer (using any of the definitions in circulation). But the notion of queering remembrance more usefully refers to the process of remembering in queer ways. In this case, it is the remembering that is queer, and not necessarily that which is being remembered.

So what would it mean to remember in queer ways, why would we want to do this, and what might we gain and lose in the process? Abelove's queer students presumably would resist a memorialization that reads as follows:

Clive Michael Boutilier, a respectable Canadian gay man deported from the United States for being gay, is a hero, a man who worked hard, attended church, and was close to his family; who was marginalized by the United States, which wanted to deport him, but who nevertheless fought back, taking his groundbreaking case all the way to the U.S. Supreme Court. The fact that he lost his case should in no way diminish his courageous accomplishments in the historic struggle for gay rights. We celebrate his life and mourn his loss.

How might we remember Boutilier differently? Textual memorials such as obituaries and oral ones such as eulogies conventionally depend on coherent and chronological life narratives, and they typically imagine family, education, work, leisure, religion, and community service as the key features of lives fully lived or tragically cut short. These narratives encourage traditional forms of mourning and celebration, not postmodern performance, critical commentary, and disorderly destabilization (Capozzola, Crimp, and Harris). What

${ }^{3}$ As an undergraduate I studied with Abelove at Wesleyan University. My years at Wesleyan (1981-85) correspond to Abelove's lesbian/gay generation, though I did not identify as gay while there. 
might a queer remembrance of Boutilier look like and what purposes would it serve?

\section{Searching for Clive}

Though I never met Boutilier, I first encountered stories about him in the early 1990s when I was researching, as part of a project on local lesbian and gay history, the Philadelphia-based Homosexual Law Reform Society (HLRS). The HLRS, which essentially was a front organization for a sexually radical faction of the homophile movement, funded and supported Boutilier's litigation (Stein, City 226-286). Reading through hundreds of pages of court records, psychiatric reports, and social movement materials, I imagined that I was catching glimpses of Boutilier, but longed to know more. Many of these texts produced, selected, arranged, organized, highlighted, and transformed pieces of information to construct a life narrative that supported particular judgments (just as the following account is constructed to support my arguments). ${ }^{4}$ According to the preponderance of evidence in these documents, many created in the constrained circumstances of legal proceedings, Boutilier was born in 1933 in Sheet Harbor, Nova Scotia. The second oldest child and oldest son in a farm family with six children, he dropped out of school at age 13 to help support his family. At some point in the next several years, Boutilier's parents divorced and his mother married a U.S. citizen. Boutilier was first admitted to the United States as a permanent resident in 1955, at age 21. He resided in the States (as did his mother, stepfather, and several siblings, nieces, and nephews) through 1963, when he applied for U.S. citizenship and revealed to a naturalization examiner that he had been arrested in New York City in 1959 on a sodomy charge, later reduced to assault and then dismissed when the 17-year-old complainant failed to appear in court. In 1964, Immigration and Naturalization Service (INS) investigator James Sarsfield interrogated him. The resulting affidavit was submitted to the Public Health Service (PHS), which certified that Boutilier was "afflicted" with "psychopathic personality" at the time of his

${ }^{4}$ Except where otherwise noted, the following paragraphs draw on the case record for Boutilier, available on microfilm in major U.S. law school libraries, and an audiotape of the oral arguments before the Supreme Court, available at the National Archives in College Park, Maryland. 
admission to the United States and therefore was subject to deportation.

According to the affidavit, when Sarsfield inquired about the acts that led to his arrest, Boutilier responded, "I inserted my penis in his rectum and had an orgasm.... [L]ater I put my penis in his mouth and had a blowjob." Boutilier affirmed that the actions had been mutually "voluntary" and said he did not recall the other person's name. Next Sarsfield asked about his sexual experiences in Canada. Boutilier reported that his "first homosexual act" took place when he was approximately 14 years old and occurred with a man who was about 40: "We had planned a hunting trip and I stayed at his home [in Pictou County] that night, his wife was away, and we shared the same bed. He tried to put his penis in my rectum. He didn't succeed but a flow of sperm came from his penis on my clothing." Boutilier told Sarsfield that his next homosexual act took place about two years later, in a public park in Halifax, Nova Scotia, where a man in his 30s (whose name he did not know) gave him a "blowjob." He then reported that between the ages of 16 and 21, he had "homosexual" sex ("all blowjobs") three to four times a year and sex with women three or four times. Asked about his sexual activities after moving to the United States, Boutilier claimed that he had sex with men three to four times a year and beginning in 1959 shared a Brooklyn apartment with Eugene O'Rourke, with whom he had sex two or three times a year. According to Boutilier, the last time he had sex with O'Rourke was about eight months earlier and the last time he had homosexual sex was about four months after that. The final questions dealt with Selective Service and the draft. Discussing why he had been classified 4F in 1957, Boutilier declared, "I'm homosexual." Sarsfield then asked, "Did they just accept your statement that you're a homosexual?" Boutilier replied, "After filling out the forms and asking the questions, I was sent to see a psychiatrist and as a result I'm classified 4F." Asked if he had anything further to add, Boutilier declared, "I plan to seek medical help and I guess that's about it. Due to the finances I couldn't get around to get this medical help before this."

Was all of this information accurate, authentic, honest, and truthful? There is no way to know. Boutilier's lawyers were not present at the 1964 interrogation but Robert Brown, who had represented him in the 1959 sodomy case, and Blanch Freedman, a 
radical lawyer affiliated with the American Committee for the Protection of the Foreign Born, represented him at a hearing before a Special Inquiry Officer in 1965. At this stage they submitted into evidence letters from two psychiatrists whom they had arranged for Boutilier to see (and who concluded that he was not psychopathic). From the start, Boutilier's lawyers and psychiatrists seem to have been doing what they could to present a sympathetic portrait of their client, whom they depicted as a good farm boy, devoted to work, family, and church, and honest to a fault. Boutilier's statements operated in similar ways, suggesting that he had been victimized by an older man and indicating that he had had sex with both women and men, had not sold or purchased sex, had almost always had sex in private, had engaged in homosexual sex infrequently, had formed a stable and domestic relationship with another man, had told the truth when questioned, and had been interested in medical help. Insofar as these strategies of respectability were functioning in larger environments of social prejudice and legal discrimination, it helped that Boutilier was male, masculine, white, Christian, and Anglophone. ${ }^{5}$

With the help of Brown and Freedman, Boutilier took his case to the Board of Immigration Appeals, which ruled against him in 1965, as did the Second Circuit Court of Appeals (in a 2-1 decision) in 1966. By this time, Boutilier and Freedman were receiving financial and legal support from the HLRS. Boutilier's appeal was heard by the Supreme Court in 1967. In their briefs, his lawyers highlighted additional information in attempting to create positive impressions of their client: Boutilier had worked "steadily" as a building maintenance man and "responsibly" as an attendant / companion to a mentally ill man; his social activities included attending mass and going bowling; he had moved back in with his mother and stepfather (who lived in the same building as O'Rourke); several of his family members were U.S. citizens, his mother was a nurse, and two of his brothers were in the U.S. military. Here it helped that Freedman was apparently married, straight, and maternal, which effectively heterosocialized and domesticated her client. One of the psychiatric letters emphasized the pain the INS had caused:

${ }^{5}$ On strategies of respectability, see Mosse and Stein, City 200-286. On prejudice and discrimination within the U.S. immigration system, see Luibheid and Ngai. 
Boutilier was cooperative during the interview but appeared extremely tense and anxious. As soon as he began to speak and from time to time throughout the interview his eyes teared. His initial spontaneous outburst was to the effect that the proceedings against him over the past six years were forcing him to make bank loans and for the first time in his life he was unable to financially cope.... The patient's present difficulties obviously weigh very heavily upon him. He feels as if he has made his life in this country and is deeply disturbed at the prospect of being cut off from the life he has created.

Beyond their efforts to elicit sympathy, Boutilier's lawyers argued that the 1952 law was unconstitutionally vague; they contended that the legislation did not intend and could not have intended to exclude all people who had ever engaged in homosexual acts; that homosexuality was best defined as a matter of conduct rather than character; that medical science no longer regarded homosexuality as intrinsically psychopathological; and that Boutilier had been deprived of his rights because he had never been examined by the PHS. In the end, however, the Court ruled 6-3 to uphold Boutilier's deportation and the law on which it was based.

Throughout the legal proceedings, Boutilier and his supporters could not fully control the impressions they created and the uses to which information about his life would be put. The evidence about his youth fit within a conventional family migration narrative, but also within psychological narratives that linked homosexuality with absent fathers, broken homes, and divorce. One psychiatrist depicted Boutilier as a son who had stood up to his father in conflicts with his mother, but this played into the stereotype that homosexuals are mamas' boys. Drawing on Boutilier's account of his first homosexual experience, some lawyers and judges described Boutilier's role as "passive," some viewed the encounter as "involuntary," and one psychiatrist wrote that Boutilier had been "seduced." When discussing his subsequent activities, Boutilier used vernacular language ("blowjobs") but the lawyers and judges preferred more formal terms ("fellatio" or "oral sex"), engaging in acts of translation with class and educational connotations. A psychiatrist wrote that Boutilier's sexual experiences before 1959 were "usually initiated" by "older men" and he "never sought out homosexual contacts or 
relationships on his own"; in contrast, the Supreme Court concluded that in these years Boutilier became an "active participant" in homosexual encounters. Boutilier's lawyers described the evidence of his homosexual activities in Canada as "meager" and one judge wrote that Boutilier had engaged in homosexual sex on a "quite infrequent" basis; however, the government's lawyers claimed the evidence was "overwhelming," they argued that Boutilier had engaged in homosexual sex on a "regular" basis, and asserted that the INS did not pursue cases involving "sporadic" homosexual acts. The Supreme Court concluded that Boutilier's homosexual condition had existed over a "continuous and uninterrupted" period of time. Meanwhile, some highlighted and others downplayed the evidence of his heterosexual activities in Canada. And while Boutilier was never asked and never volunteered information about his heterosexual activities in the United States, some suggested that he had become exclusively homosexual while others claimed that Boutilier easily moved between heterosexual and homosexual interests (and abstinence).

Other information supplied by Boutilier was also subject to interpretation, translation, and appropriation. Answering questions about the incident with the 17-year-old, Boutilier told Sarsfield, "I inserted my penis in his rectum and had an orgasm," but the Second Circuit Court referred to this as "anal sodomy" and the Supreme Court did not describe the specific sexual acts. Boutilier said the sex he had with the 17-year-old was "voluntary" on both parts, but accounts that referred to his partner's age and the "sodomy" and "assault" charges created an impression of something more sinister. As for his more recent experiences, the information that Boutilier supplied suggested multiple possibilities that were not mutually exclusive: he had formed a relatively stable and monogamous relationship with O'Rourke, he had engaged in sexual activities with anonymous partners while living with O'Rourke, he and O'Rourke had been non-exclusive sexual partners (with or without their shared knowledge and agreement), he and O'Rourke had broken up when the latter learned about his other sexual partners, and he and O'Rourke continued their relationship after he moved back in with his parents (if he really did).

Moreover, the legal record included conflicting and contradictory information. Most sources indicated that Boutilier first had same- 
sex sex when he was 14 years old, but one psychiatrist said he was 16 when this occurred. Boutilier told Sarsfield that his father had died "about 1957" and apparently told his psychiatrists this as well, but Freedman later corrected the record to indicate that his father had died in 1959. Although no source made this point, the correction meant that Boutilier experienced his father's death in April, was arrested for sodomy that October, and moved in with O'Rourke in the same year. Boutilier told Sarsfield that he had left the United States approximately four times between 1955 and 1964 (once for a two-week vacation in Trinidad and more recently for a Christmas visit to Nova Scotia in 1961), but Freedman later indicated that Boutilier left three times (including the trip to Trinidad in 1956, a Christmas visit to Nova Scotia in 1958, and a one-day trip to Nova Scotia when his father died). There was also conflicting information, possibly reflecting changes over time, about how many of Boutilier's siblings were living in the United States (three or four) and how many of his brothers were in the U.S. military (one or two). And there were disputes concerning the number of years Boutilier had engaged in homosexual acts in Canada. Boutilier referred to "six or seven" years (after the Halifax incident that occurred when he was 16 and before he entered the United States), but if Boutilier was 21 when he migrated this is impossible. Freedman pointed out in oral arguments that "actually it was only five years," but the Supreme Court referred to "more than six years" of homosexual conduct in Canada, a claim that was tenable if it incorporated the arguably "involuntary" episode that occurred when Boutilier was 14.

As I considered the multiple portraits of Boutilier evoked by these documents, it became clear that they could not easily be grouped into two clusters, one sympathetic and one critical. Nor could the legal portraits be distinguished clearly from the psychiatric ones. Those who favored a ruling against Boutilier highlighted his negative features, but insofar as they wanted to uphold the exclusion and deportation of all homosexual aliens (and not just particularly "offensive" ones), they found it useful to mention his positive features as well. In some contexts those who emphasized the Court's deference to Congress underscored this deference by insisting on its necessity despite Boutilier's many positive qualities. Meanwhile, Boutilier's supporters presented him, depending on the context, as non-homosexual, homosexual in conduct but not character, 
homosexual but not $a$ homosexual, a homosexual but not a sexual deviate, and a sexual deviate but not a psychopathic personality. The psychiatric profiles presented by his supporters denied that he was psychopathic, but referred to his "psychosexual problem," "disorder," "neurosis," and "immature" and "dependent" characteristics. One psychiatrist wrote,

What emerged out of the interview was not a picture of a psychopath but that of a dependent, immature young man with a conscience, an awareness of the feelings of others and a sense of personal honesty.... His homosexual orientation seems secondary to a very constricted, dependent personality pattern.... My own feeling is that his own need to fit in and be accepted is so great that it far surpasses his need for sex in any form.

This portrait was simultaneously sympathetic and critical, and while framed within psychiatric discourse also presented Boutilier as a migrant who wanted to "fit in."

Fascinated by these multiple stories and portraits, I nevertheless set aside my work on Boutilier for about six years as I focused on other projects. But in 1998 my interest revived when I was invited for a job interview with York University's History Department in Toronto. Aware that I would be crossing the border in the same direction taken by Boutilier in 1968, I figured, correctly as it turned out, that a department dominated by Canadian historians and Canadians would be pleased to have a U.S. historian deliver a lecture about an aspect of U.S. history that intersects with Canadian history. When I arrived in Toronto later that year to take up my position, I began looking for Boutilier. A few historians and legal scholars had written about his case, but none presented evidence beyond what was in the official record and none discussed what happened to Boutilier after he was deported. I imagined that if Boutilier was a gay man who had been forced to leave New York City, the largest U.S. city, he might be living in Canada's largest city, Toronto, which had a vibrant gay community. But my search initially turned up nothing.

After about two years of making modest efforts to find Boutilier, I turned to a genealogy website that allows family members and others to find and communicate with one another. But now I confronted ethical and political questions about how to proceed. If alive, perhaps Boutilier was not out as gay to his family or did not 
identify as gay. So I carefully worded a posting to the Boutilier family page, explaining that I was a historian researching a court case and looking for information about Clive Michael Boutilier. In March 2001, I received an email from a woman who claimed to be Boutilier's niece. After a careful exchange of several messages, I decided I could be more forthcoming. The niece did not seem to have prior knowledge of Boutilier's case, but indicated that she was going to confer with her family and shortly thereafter wrote that her uncle had been hit by a car while crossing a street in New York around the time of the Supreme Court ruling, had been in a coma for a month, and had been left brain-damaged. The niece and her siblings currently believed this was a suicide attempt caused by the Court's decision. With Boutilier requiring long-term care, his mother and stepfather moved to Niagara Falls, Ontario, where they looked after him for as long as they were able. Since the early 1990s, he had been living in group homes for the disabled. According to the niece, Boutilier looked drunk when walking, but was mobile and able to dress and feed himself. She believed he remembered his "lifestyle" because one of her nephews was gay and Boutilier once said about his grandnephew, "He has the problem, too, doesn't he?" But she also wrote, "I am sure that my grandmother drummed it into his head that what happened was to never be brought into the light of day ever again."

Again, there is no way to know whether this information is accurate, authentic, honest, and truthful. Nor can I know that the person writing to me was Boutilier's niece. Unfortunately, though the niece answered several of my questions, telling me that Boutilier was Anglophone and that the family pronounced the name "Bootlee-er," my efforts to meet Boutilier did not go anywhere. The niece wrote that under no circumstances would Boutilier's mother or sister allow me to meet him: they did "not want to open old wounds" and his mother "didn't want the subject brought up at all." Putting this together with his comment about homosexuality being a "problem," I wondered whether he had been living for decades as a gay man with significant disabilities, under the control of a homophobic mother and family. At the same time, I was aware that the family had suffered greatly because of Boutilier's "problem." Though I tried to obtain further information, offering to speak with Boutilier's mother, send questions the niece could ask him, or write to Boutilier directly, his niece was not willing or able to help in these ways. And 
insofar as she was the only family member who expressed willingness to talk with me at all (and gave me permission to quote from her messages), I did not want to alienate her.

Around this time, Joyce Murdoch and Deb Price published Courting Justice: Gay Men and Lesbians v. the Supreme Court, which featured a detailed account of the Boutilier case and an intriguing paragraph about Boutilier. According to Murdoch and Price, Boutilier was living in a rest home in "Willand, Ontario" (they were likely referring to Welland):

Speaking haltingly, he confirmed that he moved back to Canada immediately after losing his legal fight. His sevenyear relationship with Eugene O'Rouke [sic] ...was his only long-term relationship. O'Rouke [sic] has "passed away," Boutilier said. Twenty-one years after being deported, Boutilier contended that he'd made a mistake in telling the U.S. military that he was homosexual-though the records indicate his INS troubles were triggered by his citizenship application. How did he feel when he heard the court's decision? "No comment!" (132)

The references to Boutilier's living situation and "halting language" seemed consistent with what Boutilier's niece had told me. The indication that Boutilier knew that O'Rourke had died suggested several possibilities: he died before Boutilier moved back in with his parents in New York, during the time Boutilier lived with his parents there, around the time of Boutilier's "suicide attempt," or after Boutilier's return to Canada (which might mean that they remained in touch). Unfortunately, "Eugene O'Rourke" is such a common name that I was unable to find additional information about him. Boutilier's reference to his "mistake" is open to multiple interpretations, in addition to the one suggested by Murdoch and Price: he could have believed he was mistaken in telling the military that he was homosexual (in other words, that he was not) and he could have believed that had he not told the military he would have been able to withhold related information from the INS. His "no comment" is also open to multiple interpretations. ${ }^{6}$

${ }^{6}$ After reading excerpts of this essay in draft, Murdoch wrote, "My memory of my brief phone conversation with Clive Boutilier isn't crystal clear, but I do know that I had no doubt that he still thought of himself as homosexual." 
Curious about how Murdoch and Price had found Boutilier and whether they interviewed him in person or by telephone, I sent an email to the authors, one of whom explained that it had taken years to find Boutilier and that his mother had been "quite hostile-even threatening." Boutilier was "clearly in no condition to give a real interview" and "pressing him to say more would have been taking unfair advantage of what apparently is a very severe mental handicap." Not long after I received this response, Boutilier's niece wrote that her grandmother had "left strict orders that no one be allowed to confront him after the last incidence [sic]," but the niece promised me that she would speak with her sister about "the possibility of her and I and possibly you taking him out for a couple of hours." She continued, "I know that my Grandmother will be very upset after the fact because Clive tells her everything but she will get over it." Several weeks later I wrote to the niece again but did not receive a response. Some months later I sent another message and my email bounced back undelivered. I feared the trail had gone cold. Meanwhile, I had additional email exchanges with Murdoch, who wrote that she had interviewed Boutilier by telephone and that "he clearly did not want to talk at all." Because he seemed "more than a bit...addled," she "didn't press him the way [she] would have felt free to press, say, a Harvard-educated Supreme Court clerk." I asked for the telephone number and Murdoch offered to look for it, but further answers were not forthcoming.

Meanwhile, I located at the University of Michigan's Labadie Collection another significant source, Blanch Freedman's case file for "George Boutilier," which had been deposited with the papers of the American Committee for the Protection of the Foreign Born. Was the first name a product of a clerical error or evidence that Clive had been known as George in the 1960s? In this collection I found new materials about Boutilier, including a photocopy of his Canadian passport, lawyers' notes from meetings with Boutilier, letters to and from Boutilier, documents related to legal strategy, homophile fundraising materials, financial receipts, and correspondence with the Supreme Court. The photocopy of the passport indicates that Boutilier was six feet tall and had hazel eyes and brown hair. His lawyers' notes suggest that he tested positive for syphilis in 1961. There is also an ambiguous handwritten note about the Sarsfield interrogation that reads "Gibson-told truth-Gibson came to 
apartment." Was this the name of the 17-year-old? Had Boutilier feigned ignorance about Gibson's name, perhaps to protect himself or the teenager? There was also a copy of a 1963 INS affidavit (probably produced in the context of Boutilier's original citizenship application and not included in the case record), in which Boutilier indicated that he was "guilty of said violation" with the 17 -year old but subsequently "ceased to continue homosexuality." The financial materials indicate that Boutilier paid his lawyers more than $\$ 1100$ and struggled financially to do so, having lost his job because of publicity about his case.

In 2003, in the midst of the season when the U.S. Supreme Court struck down state sodomy laws in Lawrence and Canada moved closer to recognizing same-sex marriages, I received an email from Boutilier's niece, informing me that two days earlier he had died from complications related to a heart condition:

I know that he is now at peace because his life as you know was not a very comfortable one. I never did get a chance to talk with him about the past and will never know his side of the story but I am grateful that he no longer has to suffer with any prejudices of society, and I know that he can now live in the hereafter the way he truly wanted to live his life. The critical historian in me had long worried that the messages from this woman were a hoax, and sure enough when I asked to see a copy of the obituary she wrote that there had not been one ("he wanted to be cremated without any service or fuss"). But I believe that the woman who wrote to me was, indeed, Boutilier's niece, and in 2004 I obtained from the Ontario government a copy of Boutilier's death certificate, which confirmed the date of death. Whether everything the niece told me about Boutilier was entirely accurate I cannot know. Nor can she, since she did not witness any of the events in the 1950s and 1960s that she described.

In January 2005, I came across an intriguing document from the 1960 s that contained tantalizing new hints about Boutilier's postruling life. In December 1968, the newsletter of the Mattachine Society of New York, a homophile movement organization, announced that "Boutilier is in the news again." After summarizing the Supreme Court's 1967 decision, the newsletter reported, "According to a reliable source, he walked in front of a bus (whether attempted suicide or accident we don't know) and was hospitalized 
for three months. He's out now, collected a large settlement from an insurance company and is living back in Canada with his mother in a brand new house" (17). Who the "reliable" source was remains a mystery, though the information published suggests that someone with a direct or indirect connection to the homophile movement (perhaps a health care worker, INS employee, insurance industry representative, legal professional, or homophile activist) also had a direct or indirect connection to Boutilier and maintained this connection after Boutilier moved to Canada.

\section{Memory's Motivations}

Historians generally do not openly reveal much about their lives in their scholarly works (except in their acknowledgments), usually assuming objective and empirical poses, avoiding self-critical and reflexive commentary, rejecting use of the first-person voice, and concentrating on the past "as it was" rather than on dynamic relationships between present and past (Bravmann, Novick, and Turner). Many operate under the fiction that the past is knowable and retrievable and denigrate subjective interpretation as biased opinion. While historiographic training encourages practitioners to explore the influences that shaped historical interpretations produced in the past, it does not similarly encourage these scholars to explore the influences on their own interpretations. To a greater or lesser extent, many North American LGBT historians have been exceptions to this rule, exploring various links between personal presents and historical pasts (Abelove; D'Emilio; Duberman; Duggan; Duggan and Hunter; Howard; Nestle; Nestle and Preston; Rupp; SmithRosenberg; Stein, City; Stryker; and Umphrey). While some reject their approaches as narcissistic (invoking a common trope of antiLGBT prejudice), they can also be characterized as positively queer, insofar as they call attention to, and simultaneously destabilize, the performance of historical interpretation.

What, then, are the links between my personal present and Boutilier's historical past, how might answers to this question help me understand my interest in and interpretation of Boutilier's life, and how can exploration of my imagined relationship to Boutilier serve usefully queer ends? At the earliest stages of my work, I was drawn to Boutilier's story in part because of the connections I imagined between his "homosexual" identity and my "gay" one, 
between his and my histories of sex with men and women, between his life in New York City and mine in the New York suburbs in the 1960 s, and between his experiences as an immigrant and mine as the grandchild of immigrants. These identifications have been motivating and productive, but have come with associated dangers. For example, apart from a single declaration that Boutilier made in 1964 in the context of questions about how he had come to be classified as $4 \mathrm{~F}$ for the military draft ("I'm homosexual"), there is no evidence that he thought of himself as homosexual over the course of his adult life, and his declaration did not use the term "homosexual" as a noun. Boutilier's 1963 claim that he had "ceased homosexuality" and his more recent reference to the "mistake" he made in telling the military that he was homosexual suggest the possibility that at certain points in his life he did not see himself in this way. And it is possible that Boutilier told the military that he was homosexual as a way of avoiding military service for a country that had not granted him citizenship and that had recently fought a war in Korea. If I make the assumption that Boutilier identified as homosexual, my identifications may be leading me further from the evidence than I would like to go. At the same time, entertaining the possibility that he did see himself as homosexual keeps open other avenues of interpretation (allowing me, for example, to imagine him as a disabled gay man who maintained autonomy in relation to his caretaker-mother). Similarly, my identifications have encouraged me to imagine that Boutilier referred to homosexuality as a "problem" for strategic reasons (perhaps to convince the INS and the courts that he was remorseful and treatable) or because a homophobic society produced homosexuality as a problem. But it is possible that Boutilier viewed homosexuality as a problem in more traditional senses. My identifications have also encouraged me to be suspicious about Boutilier's claims that he had same-sex sex only three to four times a year and only two or three times a year with O'Rourke while they lived together, but it is possible that all of this is true.

Later, I developed additional forms of identification with Boutilier: he migrated from the United States to Canada in 1968, I did so in 1998. He was 35 years old when he moved to Canada, I was 34 . He experienced border troubles when applying for U.S. citizenship because he was taken to be "homosexual," I experienced border troubles (in the form of a special requirement that I have an 
HIV test) when applying for Canadian permanent residency, probably because I was taken to be "homosexual." $\mathrm{He}$ lived for many years as a legal alien in a country in which he was not a citizen, I do so now. Of course there are also differences in our stories. He was born into a large, Catholic, working-class farm family in Canada in the 1930s; I was born into a small, Jewish, middle-class suburban family in the United States in the 1960s. He did farm, maintenance, and personal care work, I have worked as an activist, editor, journalist, professor, and writer. I migrated semi-voluntarily (making choices constrained by the academic job market); he migrated involuntarily under a deportation order. I am allowed to return to the United States legally, he was not. The Canada to which Boutilier returned in the 1960s (which excluded "homosexual" aliens) was not the Canada that I encountered in the 1990s (which did not) (Girard and Green). Boutilier spent much of his adult life as a disabled person under the care of his family, I have spent my adult life as an able-bodied person living autonomously or with partners of my choosing.

Each of these lines of identification and disidentification have shaped and been shaped by my interpretations of Boutilier's life. For instance, my encounters with the bureaucratic machinery of border control have encouraged me to view Boutilier as a migrating subject as well as a sexual one. In turn, my encounters with Boutilier have encouraged me to be more keenly aware of what it means to live in a country in which I am not a citizen. For another example, migrating to Canada and living part-time in Maine, where a significant percentage of the population is descended from Francophone Canadians, have led me to view Boutilier as part of the FrancoCanadian diaspora, which I might not otherwise have done. My transnational existence has also contributed to my interest in the history of Canadian immigration exclusion, a topic that has helped me develop an argument about the self-defeating aspects of U.S. policy: when Canada, influenced by the United States, passed an explicit restriction on homosexual immigration in the 1950s (Girard and Green), the ironic result was a legal obstacle to the immigration of U.S. "homosexuals" to Canada, which presumably the U.S. government would have favored. When working on Boutilier more

\footnotetext{
${ }^{7}$ For a discussion, see Stein "Crossing."
} 
generally, at times I have found myself thinking, "This could have been me," but at other times I have been conscious of the ways in which my date of birth, class background, educational achievement, and able-bodied status, as well as my family's attitudes about homosexuality, have contributed to differences in our life paths.

A set of professional motivations has also influenced my interpretations. Whether the goal has been a good grade in a seminar, a research grant, a conference paper, an invited lecture, a journal article, a book contract, or a job as a professor, I have been conscious of "using" Boutilier to further my professional success. Arguably all scholars use their sources for similar purposes, but this does not mean that questions cannot be raised about the politics of these dynamics. I have been most aware of this issue when encountering the "worst" aspects of Boutilier's life. Whether it was learning about his positive syphilis test, reading about his financial struggles, finding out about his suicide attempt, or being told about his disabilities, I have been conscious of feeling great empathy, but also the guilty pleasures that come when a scholar discovers horrible details that can contribute to the production of more dramatic and poignant scholarly work. Concerned about these dynamics, I have tried to resist turning drama into melodrama.

These types of motivations have intersected with intellectual goals. For example, because much of the legal proceedings focused on whether homosexuality should be conceptualized as "conduct" or "character," and because the positions on this issue taken by the opposing lawyers are the reverse of what we have come to expect in gay rights litigation today, Boutilier's case has helped me contribute to ongoing debates about biological essentialism and social constructionism as frameworks for understanding same-sex and cross-sex sexualities. I have been able to use Boutilier to argue for the importance of the LGBT movement before the Stonewall riots (in contexts that place greater emphasis on post-Stonewall developments); the significance of sexually-radical activists who adopted respectable political strategies (a subject of my first book); the existence of LGBT rights litigation before the U.S. Supreme Court's ruling in Bowers (in contexts where scholars write as though this 1986 anti-sodomy ruling was the Court's first significant LGBT rights decision); and the value in studying the subject of my first book, Philadelphia (in contexts that highlight New York, San 
Francisco, Los Angeles, and Washington, D.C., as U.S. LGBT centers). Boutilier is also useful as a vehicle for showcasing the conservative underside of the Supreme Court's "liberal" rulings on abortion, birth control, interracial marriage, and obscenity caseshighlighting the conservatism of liberal legal strategies and emphasizing media mystification of the law (through the misreporting of legal rulings). And Boutilier's case helps me argue for the importance of transnational, border-crossing research.

Personal, professional, and intellectual motivations have all intersected with political goals as well. For example, after I learned about Boutilier's death on 12 April 2003, I very much wanted to write an article about him. "The LGBT public, the U.S. public, and the Canadian public should all know," I found myself thinking, without exactly being able to pinpoint why. I knew I did not want to write a conventional obituary, but did not know exactly what I wanted to write. A few months later, I contacted a reporter I know who writes for the Advocate, the U.S.-based gay magazine, thinking that Boutilier's death should be mentioned in a column that references the deaths of significant LGBT figures. My friend told me that too much time had passed. In the end, I decided that the kind of article I wanted to write would use Boutilier's death to make a political intervention in the contemporary world. This, I thought, was the best way to offer a useful remembrance. As I thought about what angle to take, I was reading about the mistreatment of immigrants and aliens in the United States. And so, I wrote a remembrance for the electronic History News Network that tried to connect Boutilier's case with recent developments.

I began the article, "Forgetting and Remembering A Deported Alien," with a paragraph meant to lead readers to think that I am writing about a straight man, perhaps from the Middle East, who has been caught up in the recent campaign of repression in the United States:

As far as we know, he came to the United States with his family from an economically troubled region of a U.S. ally, hoping for a better life. But he arrived at a time when the U.S. government was targetting a variety of imagined domestic and foreign enemies and was waging cold and hot wars at home and abroad. He was 21-years-old when he became a permanent resident of the United States and over 
the next decade he worked, lived, bowled, and prayed in New York. There he eventually came to share an apartment with a friend in the same Brooklyn building where his mother and stepfather lived. Two of his brothers served in the U.S. military; several of his siblings settled in the United States, married, and had children. He spoke English. As his lawyers would later make sure to emphasize, in many ways he was a model U.S. immigrant when evaluated according to dominant U.S. values. A few years after coming to the United States he was arrested for a sexual offense with a 17-yearold, but when the complainant refused to cooperate with the authorities the charges were dismissed. The more significant troubles began when he applied for citizenship and mentioned the arrest.

In the next several paragraphs, I let readers know that I was referring to Boutilier; summarized his case, and mentioned his death. With the goal of encouraging readers to make connections across different forms of discrimination against immigrants and aliens, I concluded: As the United States experiences another period in which immigrants and aliens are particularly vulnerable to the racial, religious, linguistic, class, gender, and sexual prejudices of U.S. policymakers and government officials, there is much to be learned by studying the alliances and arguments that formed around Boutilier more than 35 years ago.... The alliances that formed between civil libertarians, sexual rights activists, and immigrant advocates in Boutilier offered an important challenge to the unjust policing of U.S. borders in the 1960s. Remembering Boutilier today should remind various constituencies, including gay, lesbian, bisexual, and transgendered people; women; immigrants; ethnic, linguistic, racial, and religious minorities; and disabled people that their causes and interests are linked. Only a strong coalition of political forces has the potential to stop today's unjust exclusions, detentions, and deportations, which are raising the level of national insecurity in the United States to new heights.

Taking the risk of using Boutilier's "story" for purposes that I believe have value, I cannot know whether Boutilier would have approved. 


\section{Queer Conclusions}

By the standards established in Abelove's account of his students, this remembrance of Boutilier could be characterized as both queer and gay. I have tried to emphasize the centrality of Boutilier in the development of a heteronormative U.S. legal regime, but have also presented stories of a person quite literally expelled to and beyond the country's margins. I have attempted to avoid presenting Boutilier as a "distinct, separate, and individual" person with "deep subjectivity" (Abelove 54), but in some passages have imagined Boutilier in precisely these ways. Though at times I have offered a coherent life narrative, I have also interrupted and disrupted that narrative, keeping in mind Abelove's claim that his queer students would prefer, "insofar as persons were to be represented in history books," that such persons be "figured on the model of characters in late twentieth-century fiction rather than on the model of characters in mid-Victorian fiction" (Abelove 52). Abelove explains that queer students would prefer "characters who have indefinite boundaries, who are always slipping in and out of focus, who are never fully constituted, never reliably whole, never coherent" (52). By focusing on representations of Boutilier rather than on Boutilier himself, by encouraging critical perspectives on these representations, by emphasizing the search for Boutilier rather than my discovery of him, by asking questions that I leave unanswered, and by using various other strategies, I have tried to keep Boutilier out of focus, partial, and incoherent, though I know that sometimes he has come into clearer view. And I have attempted to place Boutilier in transnational, border-crossing frameworks, as well as in frameworks more consistent with my training as a "U.S." historian. Some of this arguably makes me a "critical" historian rather than a "gay" or "queer" one (insofar as historians are encouraged to be critical of all of their sources), but I like to think that there is something specifically gay and queer (as well as critical) about this remembrance.

By the standards of what might be called queer legal history, my work (here and in its other incarnations) could also be called both gay and queer. At times I examine LGBT subjects who are regulated by the law, at others I explore the law's constitution of LGBT and heteronormative subjects. In some contexts I focus on the law's oppression of LGBT people, in others I work on legal 
heteronormativity. Sometimes I look at the law's impact on sexed, gendered, and sexualized private and public spheres; sometimes I explore the law's deployment of sex, gender, and sexuality in the history of politics, privacy, publicity, citizenship, and the nation-state. I consider legal contexts when sexual desires, practices, and identities seem to line up, but also foreground ruptures and disjunctures between these sexual dimensions. I present stories of LGBT legal resistance that I admire, but also offer critical perspectives on LGBT political strategies. I highlight the case of a masculine, Englishspeaking, Christian white gay man, but also think about sex, gender, linguistic, and religious privilege within the law, examine the significance of Boutilier's working class and Francophone family background, and consider the law's constitution of Boutilier as disabled, both before and after his suicide attempt. And while I often privilege U.S. law in my work, I consider transnational legal dynamics as well.

Influenced by the suggestions and scholarship of others (Capazolla, Castiglia and Reed, and Halley) I have also imagined other gay and queer remembrances of Boutilier. If Tony Kushner could place Ethel Rosenberg and Roy Cohn in the same imaginative space in Angels in America, I can picture Blanch Freedman sharing her memories with Boutilier's mother, Eugene O'Rourke telling Boutilier's gay grandnephew about his great-uncle, the 40-year-old married man who shared a bed with Boutilier in Nova Scotia having a conversation with Boutilier's niece, and the 17-year-old who had sex with Boutilier talking about the experience with the high school, college, or university student who is reading this essay now. If AIDS activists can produce campy remembrances in the face of extraordinarily devastation, I can imagine working with a catty exchange about the Broadway musical Annie Get Your Gun that appeared in the footnotes of the majority and minority $2^{\text {nd }}$ Circuit Court opinions in Boutilier's case. If Janet Halley has produced a remembrance of legal scholar David Charny that wrestles with the "wish not to know" in her discussion of "the possibility that he died of the effects of a virus that he did not know he had," I can consider the silences that echo loudly in my documents about Boutilier.

Abelove concludes that his queer students were "interested in destabilizing identity in the past as well as the present" and "wanted the performance of that destabilization to be always primary." 
Pointing out that lesbian/gay works of history "historicize identity," he adds that "from historicizing to destabilizing is arguably just a step" (55). I would add that queering remembrance also involves historicizing and destabilizing history. My queer remembrance of Boutilier not only historicizes and destabilizes my subject's identity but also turns back on the remembrance and its author to historicize and destabilize both.

\section{Works Cited}

Abelove, Henry. "The Queering of Lesbian/Gay History." Radical History Review 62 (1995): 44-57.

American Committee for the Protection of the Foreign Born. Case Files: Boutilier, George. Labadie Collection, University of Michigan, Ann Arbor, MI.

Boutilier v. the Immigration and Naturalization Service. 387 U.S. 118 (1967).

Bowers v. Hardwick. 478 U.S. 186 (1986).

Bravmann, Scott. Queer Fictions of the Past: History, Culture, and Difference. New York: Cambridge UP, 1997.

Canaday, Margot. “'Who Is A Homosexual?': The Consolidation of Sexual Identities in Mid-Twentieth-Century American Immigration Law." Law and Social Inquiry 28 Spring (2003): 351386.

Capozzola, Christopher. "A Very American Epidemic: Memory Politics and Identity Politics in the AIDS Memorial Quilt, 19851993." Radical History Review 82 (2002): 91-109.

Crimp, Douglas. Melancholia and Moralism: Essays on AIDS and Queer Politics. Cambridge: MIT Press, 2002.

D'Emilio, John. Making Trouble: Essays on Gay History, Politics, and the University. New York: Routledge, 1992.

- The World Turned: Essays on Gay History, Politics, and Culture. Durham: Duke UP, 2002.

Duberman, Martin. About Time: Exploring the Gay Past. New York: Gay Presses of New York, 1991.

- Cures: A Gay Man's Odyssey. New York: Dutton, 1991.

- Left Out: The Politics of Exclusion. New York: Basic, 1999.

- Midlife Queer: Autobiography of a Decade, 1971-1981. New York: Scribner, 1996. 
114 / Stein

Duggan, Lisa. “Making It Perfectly Queer.” Socialist Review 22.1 (1992): 11-31.

and Nan D. Hunter. Sex Wars: Sexual Dissent and Political Culture. New York: Routledge, 1995.

Girard, Philip. "From Subversion to Liberation: Homosexuals and the Immigration Act, 1952-1977." Canadian Journal of Law and Society 2 (1987): 1-27.

Green, Richard. “'Give Me Your Tired, Your Poor, Your Huddled Masses' (of Heterosexuals): An Analysis of American and Canadian Immigration Policy." Anglo-American Law Review 16 (1987): 139-159.

Halley, Janet E. "In Memoriam: David Charny." Harvard Law Review 114 (2001): 2232-2234.

Harris, Daniel. "Life and Death: Some Meditations." Antioch Review 48 (1990): 415-429.

Howard, John. Men Like That: A Southern Queer History. Chicago: U of Chicago P, 1999.

Lawrence v. Texas. 538 U.S. 558 (2003).

Luibheid, Eithne. Entry Denied: Controlling Sexuality at the Border. Minneapolis: U of Minnesota P, 2002.

Mattachine Society of New York Newsletter. December 1968.

Mosse, George L. Nationalism and Sexuality: Respectability and Abnormal Sexuality in Modern Europe. New York: Howard Fertig, 1985.

Murdoch, Joyce and Deb Price, Courting Justice: Gay Men and Lesbians v. the Supreme Court. New York: Basic, 2001.

Nestle, Joan. The Persistent Desire: A Femme-Butch Reader. Boston: Alyson, 1992.

- ed. A Restricted Country. Ithaca: Firebrand Books, 1987. and John Preston, ed. Sister and Brother: Lesbians and Gay Men Write About Their Lives Together. San Francisco: Harper, 1994.

Ngai, Mae M. Impossible Subjects: Illegal Alliens and the Making of Modern America. Princeton: Princeton UP, 2004.

Novick, Peter. That Noble Dream: The "Objectivity Question" and the American Historical Profession. New York: Cambridge UP, 1988.

Rupp, Leila J. A Desired Past: A Short History of Same-Sex Love in America. Chicago: U of Chicago P, 1999. 
Smith-Rosenberg, Carroll. Disorderly Conduct: Visions of Gender in Victorian America. New York: Oxford UP, 1985.

Stein, Marc. City of Sisterly and Brotherly Loves: Lesbian and Gay Philadelphia, 1945-1972. Chicago: U of Chicago P, 2000.

- "Crossing Boarders: Memories, Dreams, Fantasies and Nightmares of the History Job Market." Left History 9.2 (Spring/ Summer 2004): 119-139.

—. "Forgetting and Remembering a Deported Alien." History News Network. 5 November 2003. http://hnn.us/articles/ 1769.html.

- "Preface." Encyclopedia of Lesbian, Gay, Bisexual, and Transgender History in America. Ed. Marc Stein. New York: Scribner's Sons, 2003. xiii-xvii.

Stryker, Susan. "Introduction: The Transgender Issue." GLQ 4.2 (1998): 146-158.

Turner, William B. A Genealogy of Queer Theory. Philadelphia: Temple UP, 2000.

Umphrey, Martha M. "The Trouble with Harry Thaw." Radical History Review 62 (1995): 8-23. 